\title{
Facile Synthesis, Characterization and Antimicrobial Activity of 2-Alkanamino Benzimidazole Derivatives
}

\author{
OLAYINKA O. AJANI ${ }^{1 *}$, DAMILOLA V. ADEROHUNMU1, \\ SHADE J. OLORUNSHOLA², CHINWE O. IKPO ${ }^{3}$ and IFEDOLAPO O. OLANREWAJU1 \\ 'Department of Chemistry, Covenant University, CST, Canaanland, \\ Km 10 Idiroko Road, P.M.B. 1023, Ota, Ogun State, Nigeria. \\ ${ }^{2}$ Department of Biological Sciences, Covenant University, CST, Canaanland, \\ Km 10 Idiroko Road, P.M.B. 1023, Ota, Ogun State, Nigeria. \\ ${ }^{3}$ Department of Chemistry, University of the Western Cape, Private Bag X17, Bellville, \\ Cape Town, 7535, South Africa. \\ *Corresponding author E-mail: ola.ajani@ covenantuniversity.edu.ng
}

http://dx.doi.org/10.13005/ojc/320111

(Received: December 19, 2015; Accepted: March 18, 2016)

ABSTRACT

Benzimidazole derivatives are known to represent a class of medicinally important compounds which are extensively used in drug design and catalysis. A series of 2-substituted benzimidazole derivatives $10 \mathrm{a}$-i was herein synthesized from the reaction of $o$-phenylenediamine with some amino acids using ameliorable pathway. The chemical structures of the synthesized compounds were confirmed by IR, UV, ${ }^{1} \mathrm{H}-\mathrm{NMR},{ }^{13} \mathrm{C}-\mathrm{NMR}$, Mass spectral and analytical data. The compounds were investigated for their antimicrobial activity alongside gentamicin clinical standard. The results showed that this skeletal framework exhibited marked potency as antimicrobial agents. The most active compound was $1 \mathrm{H}$-benzo[d]imidazol-2-yl)methanamine, $10 \mathrm{a}$.

Key words: antibacterial activity, benzimidazole, SAR study, spectral data,bioactive heterocycle.

\section{INTRODUCTION}

Over the years, the heterocyclic compounds have attracted numerous attentions due to their wide applications in medicinal chemistry research'. Nitrogen-containing heterocyclic compounds have been prominent even in early studies of chemistry. Benzimidazole is a benzo-fused imidazole which constitutes an important class of heterocyclic compound in numerous natural and synthetic compounds in medicinal chemistry for new drug development ${ }^{2}$. The most prominent benzimidazole compound in nature is $N$-ribosyldimethylbenzimidazole, which serves as an axial ligand for cobalt in vitamin $\mathrm{B}_{12}$ core $^{3}$. Diverse synthetic efforts for benzimidazoles have been 
reported, with the most common method being the heterocyclization of $o$-phenylenediamine and carboxylic acids ${ }^{2}$, aldehydes ${ }^{4}$, alcohols ${ }^{5}$ and nitriles ${ }^{6}$. This usually require strong acid, high temperature, and sometimes photo-irradiation conditions, precious metal salts ${ }^{7}$, molecular oxygen ${ }^{8}$, or 2,3dichloro-5,6-dicyano-1,4-benzoquinone as oxidant ${ }^{9}$. Iridium-catalyzed acceptor-less dehydrogenative coupling of tertiary amines was recently reported as novel strategy for the synthesis of benzimidazole ${ }^{10}$. Benzimidazole derivatives are present in numerous valuable bioactive compounds and are marketed as commercial drugs useful in human and veterinary medicines some of which are as shown in Fig. 1 as benzimidazole-based drugs ${ }^{1-9}$.
Furthermore, benzimidazole moiety is a crucial template in medicinal chemistry because of its wide variety of reported biological and pharmacological activities, some of which include anticancer ${ }^{11}$, antimicrobial ${ }^{12}$, antitumor ${ }^{13}$, antimalarial ${ }^{14}$, anti-HIV ${ }^{15}$, anti-inflammatory ${ }^{16}$, antitubercular ${ }^{17}$, anthelmintic ${ }^{18}$, anticonvulsant ${ }^{19}$, antioxidant $^{20}$, anti-ulcer ${ }^{21}$, anti-HBV ${ }^{22}$, among others. The pharmacological investigation showed that the antagonism of Ang II-induced pressure response by oral administration of a series of benzimidazole hybrid was obviously superior to that of clinical drug standard used. This result suggested that NO-releasing benzimidazole hybrids may provide a promising approach for the discovery of

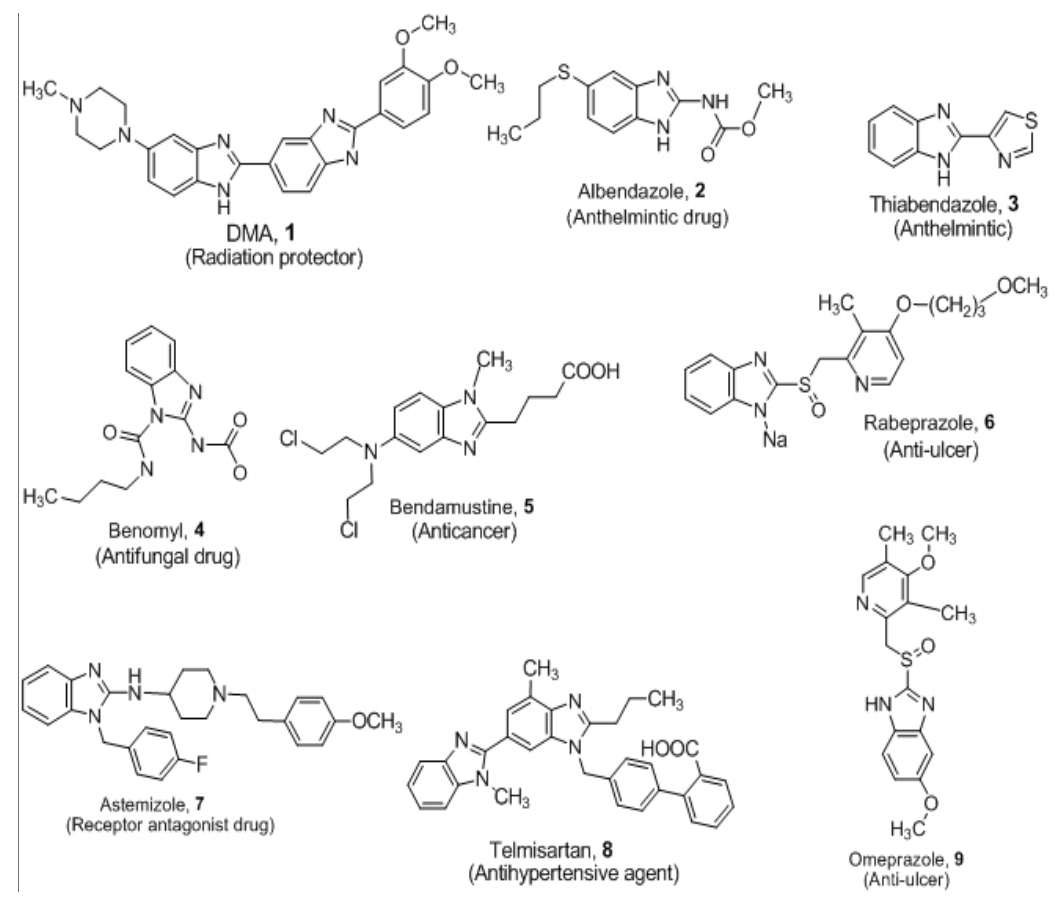

Fig. 1: Pharmaceutically important and commonly marketed benzimidazole-based drugs

novel antihypertensive agents ${ }^{23}$. Benzimidazole derivatives were recently reviewed as target agents for antidiabetic by different mechanisms such as peroxisome proliferator-activated receptor á-transcriptional activity, glycosidases receptor, dipeptidyl peptidase IV, glucokinase, human glucagon receptor (hGCGR) antagonist, aldose reductase enzyme and stearoyl-CoA desaturase ${ }^{24}$. Benzimidazole and its derivatives are reported to be physiologically and pharmacologically active and some applications are found in the treatment of several diseases including epilepsy, diabetes and infertility ${ }^{25}$. A targeted benzimidazole motif was reported by Chu et al. (2015) to potently induced apoptosis via the c-Jun $\mathrm{N}$-terminal kinase (JNK)mediated death receptor 5 up-regulation in breast cancer cells ${ }^{26}$.

In similar manner, amino acid are utilized in living cells for protein synthesis under the control of genes are in a special category since they are fundamental to all life forms as building blocks 
for peptides and proteins ${ }^{27}$. Hence, we envisage that incorporation of amino acid moieties in the benzimidazole scaffold may lead to formation of biologically relevant compounds essential in the future drug discovery.

\section{EXPERIMENTAL}

All chemical compounds and reagents used were obtained from Sigma-Aldrich Chemicals and $\mathrm{BDH}$ Chemical Companies, but were made available by Department of Chemistry, Covenant University. Solvents used were of analytical grade and were used directly without further purification. Melting points of the compounds were determined in open capillary tubes on Stuart melting point apparatus and were uncorrected. The IR spectra were run in solid state using the Bruker FT-IR while UV spectrophotometric analyses of all the samples were run in ethanol, using UV-Genesys spectrophotometer. The ${ }^{1} \mathrm{H}-\mathrm{NMR}$ and ${ }^{13} \mathrm{C}$-NMR of the compounds were run on Bruker NMR machine at 400 $\mathrm{MHz}$ and $100 \mathrm{MHz}$ respectively. The chemical shifts were measured with reference to tetramethylsilane (TMS) as internal standard and the solvent used was deuteriated DMSO. The elemental analysis (C, $\mathrm{H}, \mathrm{N}$ ) of compounds were performed using a Carlo Erba-1108 elemental analyzer. Results were found to be in good agreement with the calculated values (Table 2). The $\mathrm{pH}$ was monitored using Portable $\mathrm{pH}$ Meter Model PHB4. All drying were conducted at reduced pressure with DHG-9023A Vacuum Oven. In addition, column chromatographic purifications were carried out on the products, where necessary, using $\mathrm{CHCl}_{3} / \mathrm{CH}_{3} \mathrm{OH}$ (9:1) solvent system and Merck silica gel $F$ (Mesh 200-300). Organic solutions were dried over anhydrous $\mathrm{Na}_{2} \mathrm{SO}_{4}$ and concentrated with a RE-2000B Buchi Rotary Evaporator at reduced pressure. The progress of the reaction and the level of purity of the compounds were routinely checked by TLC on silica gel plates using different solvent system based on the variation of polarity of the product of interest and the developed plates were visualized under UV light.

\section{General procedure for synthesis of 2-substitutedbenzimidazole derivatives, 10a-i Method A}

o-Phenylenediamine $(0.54 \mathrm{~g}, 5 \mathrm{mmol})$ and required amino acid or athranilic acid $(7 \mathrm{mmol})$ were put in a round bottom flask and stirred in $20 \mathrm{ml}$ of ethanol at room temperature until the mixture showed some level of solubility. Afterward, the mixture was refluxed for about 5 minutes and solution of concentrated hydrochloric acid and water $(1: 1$ ! $1.0 \mathrm{ml})$ was added to the mixture. White fume was observed on addition of the solution. The reflux continued for $9 \mathrm{~h}$ under carefully controlled temperature of $85-95{ }^{\circ} \mathrm{C}$ until reaction was completed (TLC monitored). The product was neutralized with $40 \% \mathrm{NH}_{4} \mathrm{OH}$ and concentrated to one-third of its original volume and left in the freezer overnight for proper crystallization. The solution was then filtered by suction to afford $(1 \mathrm{H}$-benzo[d] imidazol-2-yl)methanamine, $10 \mathrm{a}$ in $68.1 \%$ yield

\section{Method B}

o-Phenylenediamine $(0.54 \mathrm{~g}, 5 \mathrm{mmol})$ and required amino acid or anthranilic acid $(7 \mathrm{mmol})$ was added sequentially to $10 \mathrm{ml}$ of toluene in a quickfit flask. The reacting mixture was heated under reflux at carefully controlled temperature of $85-95{ }^{\circ} \mathrm{C}$ for $9 \mathrm{~h}$ under the influence of a magnetic stirrer to obtain coloured solution which was allowed to cool overnight. The crystals formed was filtered and air-dried to afford (1H-benzo[d]imidazol-2-yl) methanamine, $10 \mathrm{a}$ in $97.3 \%$ yield. Due to high efficiency observed in Method B for the synthesis of $10 \mathrm{a}$, it was therefore adopted as the viable method for the synthesis of the rest of the compounds 10b-i.

\section{Synthesis of (1H-benzo[d]imidazol-2-yl) methanamine, $10 a$}

Treatment of $o$-phenylenediamine $(0.54 \mathrm{~g}$, $5 \mathrm{mmol})$ with L-glycine $(0.53 \mathrm{~g}, 7 \mathrm{mmol})$ afforded (1 H-benzo[d] imidazol-2-yl)methanamine, 10a. ${ }^{1} \mathrm{H}$ NMR (400 MHz, DMSO- $\left.d_{6}\right) \delta: 7.95(\mathrm{~s}, 1 \mathrm{H}, \mathrm{NH})$, 7.82-7.80 (d, J=8.03 Hz, 2H, Ar-H), 7.17-7.13 (m, $2 \mathrm{H}, \mathrm{Ar}-\mathrm{H}), 6.44-6.42\left(\mathrm{t}, J=5.78 \mathrm{~Hz}, 2 \mathrm{H}, \mathbf{N H}_{2}-\mathrm{CH}_{2}\right.$ ), 3.55-3.53 (t, $J=5.78 \mathrm{~Hz}, 2 \mathrm{H}, \mathrm{CH}_{2}-\mathrm{NH}_{2}$ ). ${ }^{13} \mathrm{C}-\mathrm{NMR}$ $\left(100 \mathrm{MHz}, \mathrm{DMSO}-d_{6}\right) \delta: 142.6,139.3,138.9,125.3$, $125.3,119.2,119.2,41.7$ ppm. $\lambda_{\max }$ in $\mathrm{nm}\left(\log \varepsilon_{\max }\right)$ : 236 (1.7782), 290 (1.324), 407 (0.8541). IR (KBr): $3384,3363\left(\mathrm{~N}-\mathrm{H}\right.$ of $\mathrm{NH}_{2}$, two bands), $3245(\mathrm{~N}-\mathrm{H})$, 3021 (C-H aromatic), 2930 (C-H aliphatic), 1605 $(\mathrm{C}=\mathrm{C}), 1580(\mathrm{C}=\mathrm{N}), 741(\mathrm{Ar}-\mathrm{H}) \mathrm{cm}^{-1}$. MS: in m/z (rel. $\%): 295.04(2 \mathrm{M}+1,10.5 \%), 148.01(\mathrm{MH}, 24.5 \%)$, $147.03\left(\mathrm{M}^{+}, 20 \%\right), 132.04(\mathrm{M}-\mathrm{NH}, 100 \%), 118.07$ $\left(\mathrm{M}-\mathrm{CH}_{2}=\mathrm{NH}, 35.3 \%\right), 76.11(68.3 \%)$. 
Synthesis of 1-(1H-benzo[d]imidazol-2-yl)-2methylpropan-1-amine, 10b

Treatment of $o$-phenylenediamine $(0.54 \mathrm{~g}, 5$ $\mathrm{mmol})$ and L-valine $(0.82 \mathrm{~g}, 7 \mathrm{mmol})$ afforded $1-(1 \mathrm{H}-$ benzo[d] imidazol-2-yl)-2-methylpropan-1-amine, 10b. ${ }^{1} \mathrm{H}-\mathrm{NMR}\left(400 \mathrm{MHz}, \mathrm{DMSO}-d_{6}\right) \delta: 8.01$ (s, $1 \mathrm{H}$, $\mathrm{NH}), 7.67-7.65(\mathrm{~d}, J=8.00 \mathrm{~Hz}, 2 \mathrm{H}, \mathrm{Ar}-\mathrm{H}), 7.11-7.07$ (m, $2 \mathrm{H}, \mathrm{Ar}-\mathrm{H}), 6.23-6.21$ (d, $J=6.28 \mathrm{~Hz}, 2 \mathrm{H}, \mathbf{N H}_{2}-$ $\mathrm{CH})$, 2.73-2.69 (dt, $J_{1}=4.34 \mathrm{~Hz}, J_{1}=6.28 \mathrm{~Hz}, 1 \mathrm{H}$, $\left.\mathrm{CH}-\mathrm{CH}_{2}-\mathrm{NH}_{2}\right), 1.68\left(\mathrm{~m}, 1 \mathrm{H}, \mathrm{CH}-\mathrm{CH}-\left(\mathrm{CH}_{3}\right)_{2}\right), 0.99(\mathrm{~d}$, $\left.J=4.34 \mathrm{~Hz}, 3 \mathrm{H}, \mathrm{CH}_{3}-\mathrm{CH}\right), 0.93(\mathrm{~d}, J=4.35 \mathrm{~Hz}, 3 \mathrm{H}$, $\left.\mathrm{CH}_{3}-\mathrm{CH}\right) \cdot{ }^{13} \mathrm{C}-\mathrm{NMR}\left(100 \mathrm{MHz}\right.$, DMSO- $\left.d_{6}\right) \delta: 143.1$, 138.2, 138.1, 125.7, 125.7, 118.5, 118.5, $44.7(\mathrm{CH})$, $38.9(\mathrm{CH}), 18.7\left(2 \times \mathrm{CH}_{3}\right)$ ppm. $\lambda_{\max }$ in $\mathrm{nm}\left(\log \varepsilon_{\max }\right)$ : 209 (3.3653), 236 (2.893), 293 (2.5185). IR (KBr): 3384, $3363\left(\mathrm{~N}-\mathrm{H}\right.$ of $\mathrm{NH}_{2}$, two bands), $3117(\mathrm{~N}-\mathrm{H})$, 2962 (C-H aliphatic of $\mathrm{CH}_{3}$ ), 1603 ( $\mathrm{C}=\mathrm{C}$ aromatic), $1591(\mathrm{C}=\mathrm{N}), 775(\mathrm{Ar}-\mathrm{H}) \mathrm{cm}^{-1}$. MS: in $\mathrm{m} / \mathrm{z}$ (rel. \%): $189.15\left(\mathrm{M}^{+}, 100 \%\right), 174.13(\mathrm{M}-\mathrm{NH}, 66.3 \%), 147.16$ $\left(\mathrm{M}-\mathrm{CH}\left(\mathrm{CH}_{3}\right)_{2}\right), 132.12$ (34.2\%), 106.11 (23.4\%), $76.14(44.3 \%)$.

\section{Synthesis of 4-amino-4-(1 H-benzo[d]imidazol-2-} yl)butanamide (10c)

Treatment of $o$-phenylenediamine $(0.54 \mathrm{~g}$, $5 \mathrm{mmol})$ with L-glutamine $(1.02 \mathrm{~g}, 7 \mathrm{mmol})$ afforded 4-amino-4-(1 H-benzo[d]imidazol-2-yl)butanamide, 10c. ${ }^{1} \mathrm{H}-\mathrm{NMR}\left(400 \mathrm{MHz}, \mathrm{DMSO}-d_{6}\right) \delta: 11.21$ (s, $2 \mathrm{H}$, $\mathrm{NH}_{2}-\mathrm{C}=\mathrm{O}$ ), $8.27(\mathrm{~s}, 1 \mathrm{H}, \mathrm{NH}), 7.53-7.51$ (d, $J=8.00$ $\mathrm{Hz}, 2 \mathrm{H}$, Ar-H), 7.19-7.15 (m, 2H, Ar-H), 6.29-6.27 (d, $J=6.51 \mathrm{~Hz}, 2 \mathrm{H}, \mathrm{NH}_{2}-\mathrm{CH}$ ), 4.11-4.10 (t, $J=4.35$ $\mathrm{Hz}, 1 \mathrm{H}, \mathrm{CH}-\mathrm{CH}_{2}$ ), 2.94-2.92 (t, $J=7.85 \mathrm{~Hz}, 2 \mathrm{H}$, $\left.\mathrm{CH}_{2}-\mathrm{CH}_{2}\right), 2.77-2.74\left(\mathrm{~m}, 2 \mathrm{H}, \mathrm{CH}_{2}\right) .{ }^{13} \mathrm{C}-\mathrm{NMR}(100$ $\mathrm{MHz}$, DMSO- $\left.d_{6}\right) \mathrm{d}: 178.3(\mathrm{C}=\mathrm{O}), 145.3,139.2,139.1$, 126.5, 126.5, 119.2, 119.2, $55.8(\mathrm{CH}), 34.6\left(\mathrm{CH}_{2}\right)$, $34.1\left(\mathrm{CH}_{2}\right)$ ppm. $\lambda_{\max }$ in $\mathrm{nm}\left(\log \varepsilon_{\max }\right): 209$ (3.2842), 236 (3.1562), 293 (2.3054). IR (KBr): 3384, 3364 $\left(\mathrm{N}-\mathrm{H}\right.$ of $\mathrm{NH}_{2}$, two bands), $3235(\mathrm{~N}-\mathrm{H}), 3200(\mathrm{~N}-\mathrm{H})$, 2927 (C-H aliphatic of $\mathrm{CH}_{2}$ ), 2803 (C-H aliphatic), 1685 ( $\mathrm{C}=\mathrm{O}$ of amide), 1605 ( $\mathrm{C}=\mathrm{C}$ aromatic), $1575(\mathrm{C}=\mathrm{N}), 748(\mathrm{Ar}-\mathrm{H}) \mathrm{cm}^{-1}$. MS: in $\mathrm{m} / \mathrm{z}(\mathrm{rel} . \%)$ : 245.11 (48.1\%), $236.14\left(\mathrm{M}+\mathrm{H}_{2} \mathrm{O}, 100 \%\right), 218.15$ $\left(\mathrm{M}^{+}, 65.7 \%\right), 175.14(\mathrm{M}-\mathrm{CONH}, 22.4 \%), 147.14$ $(45.7 \%)$.

\section{Synthesis of 2-(pyrrolidin-2-yl)-1 H-benzo[d] imidazole, 10d}

Treatment of $o$-phenylenediamine $(0.54$ $\mathrm{g}, 5 \mathrm{mmol})$ with L-proline $(0.81 \mathrm{~g}, 7 \mathrm{mmol})$ afforded 2-(pyrrolidin-2-yl)-1 $\mathrm{H}$-benzo[d] imidazole, $10 \mathrm{~d} .{ }^{1} \mathrm{H}$ -
$\operatorname{NMR}\left(400 \mathrm{MHz}, \mathrm{DMSO}-d_{6}\right) \delta: 8.21(\mathrm{~s}, 1 \mathrm{H}, \mathrm{NH}), 7.61-$ $7.59(\mathrm{~d}, J=8.00 \mathrm{~Hz}, 2 \mathrm{H}, \mathrm{Ar}-\mathrm{H}), 7.13-7.10(\mathrm{~m}, 2 \mathrm{H}$, Ar-H), 5.98-5.96 (m, 1H, NH of pyrrolo-), 3.98-3.97 (t, $\left.J=4.91 \mathrm{~Hz}, 1 \mathrm{H}, \mathrm{CH}-\mathrm{CH}_{2}\right), 2.87-2.85$ (t, $J=7.23 \mathrm{~Hz}$, $\left.2 \mathrm{H}, \mathrm{CH}_{2}-\mathrm{CH}_{2}\right), 2.09-2.05\left(\mathrm{~m}, 2 \mathrm{H}, \mathrm{CH}_{2}\right), 1.94-1.90(\mathrm{~m}$, $\left.2 \mathrm{H}, \mathrm{CH}_{2}\right) \cdot{ }^{13} \mathrm{C}-\mathrm{NMR}\left(100 \mathrm{MHz}\right.$, DMSO- $\left.d_{6}\right) \delta: 144.9$, 139.6, 139.5, 127.2, 127.2, 118.9, 118.9, $61.8(\mathrm{CH})$, $45.33\left(\mathrm{CH}_{2}\right), 36.5\left(\mathrm{CH}_{2}\right), 25.7\left(\mathrm{CH}_{2}\right) \cdot \lambda_{\text {max }}$ in $\mathrm{nm}(\mathrm{log}$ $\left.\varepsilon_{\max }\right): 209$ (3.3520), 239 (2.6522), 293 (2.2810). IR $(\mathrm{KBr}): 3322(\mathrm{~N}-\mathrm{H}), 3124(\mathrm{~N}-\mathrm{H}$ aliphatic), $3027(\mathrm{C}-\mathrm{H}$ aromatic), 2928 (C-H aliphatic of $\left.\mathrm{CH}_{2}\right), 2857(\mathrm{C}-\mathrm{H}$ aliphatic), 1600 ( $\mathrm{C}=\mathrm{C}$ aromatic), $1577(\mathrm{C}=\mathrm{N}), 744$ (Ar-H) $\mathrm{cm}^{-1}$. MS: in m/z (rel. \%): 204.13 (67.5\%), $187.15\left(\mathrm{M}^{+}, 100 \%\right), 119.14$ (73.32\%), $106.13(100 \%)$, $77.04(32.11 \%)$.

\section{Synthesis of 4-(2-amino-2-(1 H-benzo[d]imidazol- 2-yl)ethyl)phenol, 10e}

Treatment of $o$-phenylenediamine $(0.54 \mathrm{~g}, 5$ $\mathrm{mmol})$ with L-tyrosine (1.27 g, $7 \mathrm{mmol})$ afforded 4-(2amino-2-(1 H-benzo[d]imidazol-2-yl)ethyl)phenol, 10e. ${ }^{1} \mathrm{H}-\mathrm{NMR}\left(400 \mathrm{MHz}, \mathrm{DMSO}-d_{6}\right) \delta: 8.21(\mathrm{~s}, 1 \mathrm{H}$, $\mathrm{NH})$, 7.69-7.67 (d, $J=8.26 \mathrm{~Hz}, 2 \mathrm{H}$, Ar-H of OTs), 7.59-7.57 (m, 2H, Ar-H), 7.03-7.01 (d, $J=8.40 \mathrm{~Hz}$, $2 \mathrm{H}, \mathrm{Ar}-\mathrm{H}$ of benzyl), 6.85-6.83 (d, $J=8.40 \mathrm{~Hz}, 2 \mathrm{H}$, Ar-H of benzyl), $5.14-5.12\left(\mathrm{~d}, J=8.50 \mathrm{~Hz}, 1 \mathrm{H}, \mathbf{N H}_{2}-\right.$ $\mathrm{CH}), 4.17-4.12\left(\mathrm{~m}, 1 \mathrm{H}, \mathrm{NH}_{2}-\mathrm{CH}-\mathrm{CH}_{2}\right), 3.11-3.06$ (dd, $J_{1}=5.20 \mathrm{~Hz}, J_{2}=20.00 \mathrm{~Hz}, 1 \mathrm{H}, \mathrm{CH}$ of $\mathrm{CH}_{2}-\mathrm{Ar}$ ), 2.97$2.92\left(\mathrm{dd}, \mathrm{J}_{1}=6.80 \mathrm{~Hz}, \mathrm{~J}_{2}=20.00 \mathrm{~Hz}, 1 \mathrm{H}, \mathrm{CH}\right.$ of $\mathrm{CH}_{2}-$ Ar). $\lambda_{\max }$ in $n m\left(\log \varepsilon_{\max }\right): 209$ (3.3677), 236 (2.796), 293 (2.4698). IR (KBr): 3384, $3363\left(\mathrm{~N}-\mathrm{H}\right.$ of $\mathrm{NH}_{2}$, two bands), $3200(\mathrm{~N}-\mathrm{H}), 3117$ (O-H, broad), 2929 (C-H aliphatic of $\mathrm{CH}_{2}$ ), 2876, 2827 (C-H aliphatic), 1600 $\left(\mathrm{C}=\mathrm{C}\right.$ aromatic), $1584(\mathrm{C}=\mathrm{N}), 739(\mathrm{Ar}-\mathrm{H}) \mathrm{cm}^{-1}$. MS: in $\mathrm{m} / \mathrm{z}$ (rel. \%): $253.17\left(\mathrm{M}^{+}, 96.7 \%\right), 236.13(\mathrm{M}-\mathrm{OH}$, 77.2\%), $221.16(\mathrm{M}-\mathrm{NHOH}, 82.3 \%), 187.15(58.1 \%)$, 119.14 (73.32\%), 106.13 (100\%), 77.14 (19.3\%).

\section{Synthesis of 1-(1H-benzo[d]imidazol-2-yl)-2- phenylethanamine, $10 \mathrm{f}$}

Treatment of $o$-phenylenediamine $(0.54 \mathrm{~g}, 5$ $\mathrm{mmol})$ with L-phenylalanine $(1.16 \mathrm{~g}, 7 \mathrm{mmol})$ afforded 1-(1H-benzo [d] imidazol-2-yl)-2-phenylethanamine, 10f. ${ }^{1} \mathrm{H}-\mathrm{NMR}\left(400 \mathrm{MHz}\right.$, DMSO- $\left.d_{6}\right) \delta: 8.23(\mathrm{~s}, 1 \mathrm{H}$, $\mathrm{NH}), 7.63-7.61(\mathrm{~d}, J=8.26 \mathrm{~Hz}, 2 \mathrm{H}, \mathrm{Ar}-\mathrm{H}), 7.57-7.55$ $(\mathrm{m}, 2 \mathrm{H}, \mathrm{Ar}-\mathrm{H}), 7.24-7.21(\mathrm{~m}, 5 \mathrm{H}, \mathrm{Ar}-\mathrm{H}$ of benzyl), 5.14-5.12 (d, $\left.J=8.45 \mathrm{~Hz}, 1 \mathrm{H}, \mathrm{NH}_{2}-\mathrm{CH}\right), 4.22-4.17$ (m, $1 \mathrm{H}, \mathrm{CH}$ ), 3.12-3.08 (dd, $J_{1}=5.60 \mathrm{~Hz}, J_{2}=20$ $\mathrm{Hz}, 1 \mathrm{H}), 3.03-2.98\left(\mathrm{dd}, J_{1}=6.40 \mathrm{~Hz}, J_{2}=20 \mathrm{~Hz}\right.$, 1H). ${ }^{13} \mathrm{C}-\mathrm{NMR}\left(100 \mathrm{MHz}\right.$, DMSO- $\left.d_{6}\right) \delta: 143.9,136.6$, 
134.9, 129.8 (2CH aromatic), 129.6 (2CH aromatic), 128.8 (2CH aromatic), 127.5, 127.2 (2CH aromatic), 119.5, 56.5, $39.0\left(\mathrm{CH}_{2}\right), 21.7\left(\mathrm{CH}_{3}\right) \cdot \lambda_{\max }$ in $\mathrm{nm}(\mathrm{log}$ $\left.\varepsilon_{\text {max }}\right)$ : 212 (3.4050), 236 (2.9974), 293 (2.6857). IR (KBr): 3384, 3363 (N-H of $\mathrm{NH}_{2}$, two bands), 3209 $(\mathrm{N}-\mathrm{H}), 3022$ ( $\mathrm{C}=\mathrm{H}$ aromatic), 2889 (C-H aliphatic), 1615 (C=C aromatic), $1575(\mathrm{C}=\mathrm{N}), 749(\mathrm{Ar}-\mathrm{H}) \mathrm{cm}^{-1}$. MS: in m/z (rel. \%): $237.09\left(\mathrm{M}^{+}, 94.5 \%\right), 236.08(\mathrm{M}-$ $\mathrm{H}, 67.9 \%), 217.11$ (58.4\%), 187.15 (58.1\%), 119.14 (73.7\%), 106.09 (100\%), $77.12(40.7 \%)$.

\section{Synthesis of 1-(1 H-benzo[d]imidazol-2-yl)-3-} (methylthio)propan-1-amine, $10 \mathrm{~g}$

Treatment of $o$-phenylenediamine $(0.54 \mathrm{~g}$, $5 \mathrm{mmol}$ ) with L-methionine $(1.04 \mathrm{~g}, 7 \mathrm{mmol}$ ) afforded 1-(1 H-benzo [d]imidazol-2-yl)-3-(methylthio)propan1-amine, 10g. ${ }^{1} \mathrm{H}-\mathrm{NMR}\left(400 \mathrm{MHz}, \mathrm{DMSO}-d_{6}\right) \mathrm{d}$ : $8.23(\mathrm{~s}, 1 \mathrm{H}, \mathrm{NH}), 7.75-7.73(\mathrm{~d}, J=8 \mathrm{~Hz}, 2 \mathrm{H}, \mathrm{Ar}-\mathrm{H})$, 7.29-7.27 (m, 2H, Ar-H), 5.68-5.66 (d, J = 7.55 Hz, $\left.2 \mathrm{H}, \mathrm{NH}_{2}-\mathrm{CH}\right), 2.50-2.48(\mathrm{~m}, 1 \mathrm{H}, \mathrm{CH}), 2.35-2.33(\mathrm{t}$, $\left.J=8.88 \mathrm{~Hz}, 2 \mathrm{H}, \mathrm{CH}_{2}-\mathrm{CH}_{2}-\mathrm{S}\right), 1.97$ (s, 3H, $\left.\mathrm{CH}_{3}-\mathrm{S}\right)$, 1.82-1.73 (m, 2H, CH-CH $\left.-\mathrm{CH}_{2}\right) \cdot{ }^{13} \mathrm{C}-\mathrm{NMR}(100 \mathrm{MHz}$, DMSO- $\left.d_{6}\right) \delta: 145.3,139.3,139.1,126.9,126.9$, 117.3, 117.3, $58.2(\mathrm{CH}), 43.7\left(\mathrm{CH}_{2}\right), 31.2\left(\mathrm{CH}_{2}\right)$, $15.9\left(\mathrm{CH}_{3}\right) \cdot \lambda_{\max }$ in $\mathrm{nm}\left(\log \varepsilon_{\max }\right): 209$ (3.3181), 236 (2.6064), 293 (2.2553). IR (KBr): 3384, $3363(\mathrm{~N}-\mathrm{H}$ of $\mathrm{NH}_{2}$, two bands), $3276(\mathrm{~N}-\mathrm{H}), 3173(\mathrm{~N}-\mathrm{H}), 3029$ (C-H aromatic), $2921\left(\mathrm{C}-\mathrm{H}\right.$ aliphatic of $\left.\mathrm{CH}_{2}\right), 2885$ (C-H aliphatic), $1600(\mathrm{C}=\mathrm{C}), 1575(\mathrm{C}=\mathrm{N}), 745(\mathrm{Ar}-\mathrm{H})$ $\mathrm{cm}^{-1}$. MS: in m/z (rel. \%): $221.08\left(\mathrm{M}^{+}, 75.9 \%\right), 195.07$ (51.7\%), 182.07 (82.5\%), $164.07\left(\mathrm{M}-\mathrm{SCH}_{3}, 89.3 \%\right)$, 106.09 (100\%), $77.12(40.7 \%)$.

\section{Synthesis of 1-(1H-benzo[d]imidazol-2-yl) pentane-1,5-diamine, $10 \mathrm{~h}$}

Treatment of $o$-phenylenediamine $(0.54$ $\mathrm{g}, 5 \mathrm{mmol})$ with L-lysine $(1.28 \mathrm{~g}, 7 \mathrm{mmol})$ afforded 1-(1 H-benzo[d]imidazol-2-yl)pentane-1,5-diamine, 10h. ${ }^{1} \mathrm{H}-\mathrm{NMR}$ (400 MHz, DMSO- $\left.d_{6}\right) \delta: 8.51$ (s, $1 \mathrm{H}$, $\mathrm{NH}), 7.78-7.76(\mathrm{~d}, J=8 \mathrm{~Hz}, 2 \mathrm{H}, \mathrm{Ar}-\mathrm{H}), 7.37-7.34$ (m, 2H, Ar-H), 6.23-6.21 (d, J = 7.75 Hz, 2H, $\mathrm{NH}_{2}-$ $\mathrm{CH}$ ), 5.97-5.94 (t, $J=8.04 \mathrm{~Hz}, 2 \mathrm{H}, \mathbf{N H}_{2}-\mathrm{CH}_{2}$ ), 3.91$3.94(\mathrm{~m}, 1 \mathrm{H}, \mathrm{CH}), 2.35-2.33(\mathrm{t}, J=8.04 \mathrm{~Hz}, 2 \mathrm{H}$, $\mathrm{CH}_{2}-\mathrm{CH}_{2}-\mathrm{NH}_{2}$ ), 2.13-2.11 (quintet, $J=8.17 \mathrm{~Hz}, 2 \mathrm{H}$, $\mathrm{CH}_{2}-\mathrm{CH}_{2}-\mathrm{CH}_{2}$ ), 1.92-1.90 (quintet, $\mathrm{J}=8.14 \mathrm{~Hz}, 2 \mathrm{H}$, $\left.\mathrm{CH}_{2}-\mathrm{CH}_{2}-\mathrm{CH}_{2}\right), 1.82-1.73\left(\mathrm{~m}, 2 \mathrm{H}, \mathrm{CH}-\mathrm{CH}_{2}-\mathrm{CH}_{2}\right) \cdot{ }^{13} \mathrm{C}-$ NMR (100 MHz, DMSO- $\left.d_{6}\right) \delta: 145.3,139.6,139.4$, 126.7, 126.7, 119.9, 119.9, 55.8, 43.1, 39.6, 32.9, 21.5 ppm. $\lambda_{\max }$ in $\mathrm{nm}\left(\log \varepsilon_{\max }\right): 206$ (2.6222), 236 (1.5911), 296 (0.6021). IR (KBr): 3383, 3365 (N-H of $\mathrm{NH}_{2}$, two bands), $3276(\mathrm{~N}-\mathrm{H}), 3173(\mathrm{~N}-\mathrm{H}), 3026$ (C-H aromatic), 2929 (C-H aliphatic of $\mathrm{CH}_{2}$ ), 2845 (C-H aliphatic), $1603(\mathrm{C}=\mathrm{C}$ aromatic), $1583(\mathrm{C}=\mathrm{N})$, $742(\mathrm{Ar}-\mathrm{H}) \mathrm{cm}^{-1}$. MS: in m/z (rel. \%): $218.17\left(\mathrm{M}^{+}\right.$, 89.3\%), 190.17 (M - N2, 100\%), 162.16 (73.5\%), 145.03 (41.6\%), 106.15 (96.2\%), 77.17 (40.7\%).

\section{Synthesis of 2-(1H-benzo[ $d]$ imidazol-2-yl)aniline, $10 i$}

Treatment of o-phenylenediamine $(0.54 \mathrm{~g}, 5$ $\mathrm{mmol})$ with anthranilic acid $(0.96 \mathrm{~g}, 7 \mathrm{mmol})$ afforded 2-(1 H-benzo [d] imidazol-2-yl)aniline, 10i. ${ }^{1} \mathrm{H}-\mathrm{NMR}$ $\left(400 \mathrm{MHz}, \mathrm{DMSO}-d_{6}\right) \delta: 11.13\left(\mathrm{~s}, 2 \mathrm{H}, \mathrm{NH}_{2}\right), 8.49$ (s, 1H, NH), 7.96-7.94 (d, J = 8.08 Hz, 2H, Ar-H), 7.78-7.76 (d, J=8.00 Hz, 2H, Ar-H), 7.37-7.34 (m, $2 \mathrm{H}, \mathrm{Ar}-\mathrm{H}), 6.87-6.85$ (m, 2H, Ar-H). ${ }^{13} \mathrm{C}-\mathrm{NMR}(100$ $\left.\mathrm{MHz}, \mathrm{DMSO}-d_{6}\right) \mathrm{d}: 147.4,143.2,139.5,139.3,139.1$, 128.1, 128.0, 126.7, 126.5, 119.8, 119.7, 119.3, 119.2 ppm. $\lambda_{\max }$ in $\mathrm{nm}\left(\log \varepsilon_{\max }\right): 209$ (3.1553), 242 (2.4914), 335 (2.0899). IR (KBr): 3384, 3366 (N-H of $\mathrm{NH}_{2}$, two bands), $3201(\mathrm{~N}-\mathrm{H}), 3031$ (C-H aromatic), $1576(\mathrm{C}=\mathrm{N}), 748(\mathrm{Ar}-\mathrm{H}) \mathrm{cm}^{-1}$. MS: in $\mathrm{m} / \mathrm{z}$ (rel. \%): $209.23\left(\mathrm{M}^{+}, 76.5 \%\right), 194.25(\mathrm{M}-\mathrm{NH}, 91.4 \%), 118$. 22 (44.24\%), 106.15 (100\%), 77.25 (38.2\%).

\section{Antimicrobial Activity}

The antimicrobial properties of the 2-substituted benzimidazole derivatives were investigated in form of the general sensitivity testing with respect to six targeted organisms. The six organisms of interest in this present study are Staphylococcus aureus, Proteus vulgaris, Streptococcus faecalis, Klebsiella pneumonia, Pseudomonas aeruginosa and Escherichia coli which pose serious threat to life of man and animals from time to time. They are associated with the gastrointestinal tract damage in man and animal.

\section{Antibacterial Sensitivity Testing of Compounds}

All the synthesized benzimidazole templates and gentamicin were screened for antibacterial activity on the targeted organisms mentioned above using agar well diffusion method ${ }^{29}$. The medium employed was diagnostic sensitivity test agar (Biotech Ltd). With the aid of a sterile $1 \mathrm{~mL}$ pipette, about $0.2 \mathrm{~mL}$ of the broth culture of test organism was added to $18 \mathrm{~mL}$ sterile molten diagnostic sensitivity test agar (Biotech Ltd) which had already cooled down to $45^{\circ} \mathrm{C}$. This was well mixed and poured into previously sterilized petri dishes, which 
had been properly labeled according to the test organisms. The medium was then allowed to set. With the aid of a sterile cork borer, the required numbers of holes were bored into the medium. The wells were made of about $5 \mathrm{~mm}$ to the edge of the plate. The wells were then filled up aseptically with the solution of the compound in DMSO using Pasteur pipettes. Gentamicin was used as the standard antibacterial agent at a concentration of $1000 \mu \mathrm{g} / \mathrm{mL}$. The plates were allowed to stand for about $1 \mathrm{~h}$ on the bench for proper diffusion of the antibacterial agents into the medium and then incubated uprightly at $37^{\circ} \mathrm{C}$ for $24 \mathrm{~h}$. Care was taken not to stockpile the plates. Clear zones of inhibition (Z.O.I.) in millimeters ( $\mathrm{mm}$ ) indicated the relative susceptibility of the bacteria to the compounds and Gentamicin clinical reference.

\section{RESULTS AND DISCUSSION}

In the continuation of our effort on the synthesis of substituted benzimidazole as viable heterocyclic compounds for the possible antimicrobial evaluation ${ }^{2}$, we have herein reported synthesis of alkanamino substituted benzimidazole. Generally, as far as synthesis is concerned, the alkanaminobenzimidazole derivatives 10a-h were obtained in $83.3-97.3 \%$ yields by the direct [4+1]-cycloaddition of various amino acids with o-phenylenediamine and the pathway is as shown in Scheme 1. In a similar manner, when the condensation was carried out using anthranilic acid as the lone pair acceptor with $\mathrm{sp}^{2}$ hybridized carbon, 2-(1H-benzo[ $\left.d\right]$ imidazol-2-yl) aniline, $10 \mathrm{i}$ was obtained in $83.4 \%$ yield. In detail,

Table 1: Comparative study of catalyzed and non-catalyzed synthesis of $10 a$

\begin{tabular}{llcccc}
\hline Entry & Solvent & Catalyst & Temperature ${ }^{\circ} \mathbf{C}$ & Time $\mathbf{h}$ & Yield \% \\
\hline Method A & Ethanol & $\mathrm{HCl} / \mathrm{H} 2 \mathrm{O}$ & $85-95$ & 9 & 68.1 \\
Method B & Toluene & No catalyst & $85-95$ & 9 & 97.1 \\
\hline
\end{tabular}

Method A: Catalyzed synthetic approach using HCl:H2O (1:1). Method B: Non-catalyzed but solvent dependent synthetic approach in toluene.

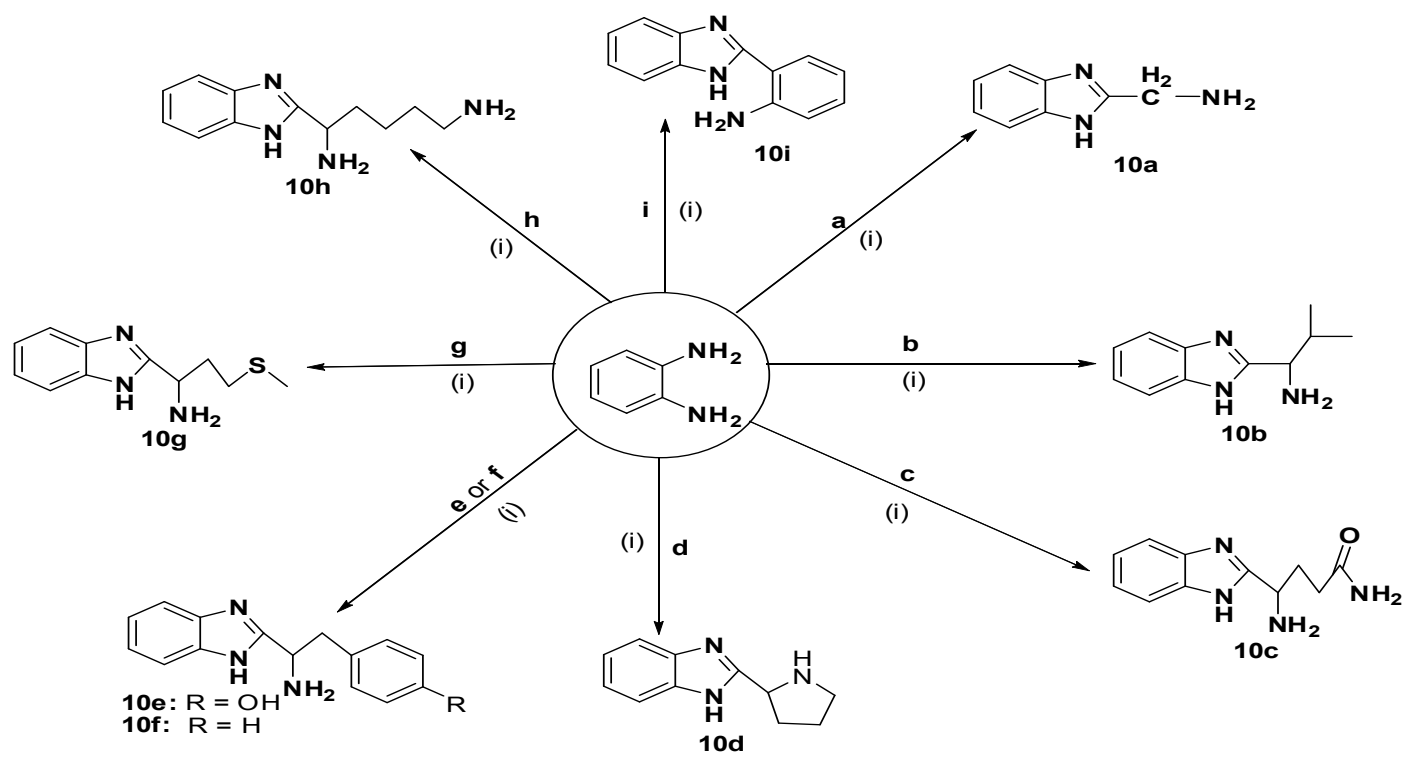

Reaction conditions \& amino acid reagents used: (i) Method A: EtOH, $\mathrm{H}_{2} \mathrm{O}: \mathrm{HCl}(1 \mathrm{ml})$, refluxed for $9 \mathrm{~h}$. Method B: Toluene, refluxed for $9 \mathrm{~h}$. $\mathbf{a}=$ Glycine, $\mathbf{b}=\mathrm{L}-\mathrm{V}$ aline, $\mathbf{c}=\mathrm{L}-$ Glutamine, $\mathbf{d}=$ L-Proline, $\mathbf{e}=$ L-Tyrosine, $\mathbf{f}=$ L-Phenylalanine, $\mathbf{g}=$ L-Methionine, $\mathbf{h}=$ L-Lysine, $\mathbf{i}=$ Anthranilic acid .

Scheme 1: Synthesis of alkanamido benzimidazole derivatives, 10a-i 
preliminary optimization of reaction conditions was done by comparing the synthesis of 10a under two different Methods. Method $A$ involves the refluxing of ethanolic solution of $o$-phenylenediamine with glycine in $\mathrm{HCl} / \mathrm{H}_{2} \mathrm{O}(1: 1 \rightarrow 1.0 \mathrm{ml})$ medium as described in our previous work ${ }^{2}$. The newly established method herein involves the synthesis in non-catalyzed medium but with toluene solvent (Method B). Firstly, the thermodynamic evaluation was carried out to establish the optimum temperature of the reaction condition which was found to be between 85 and $95^{\circ} \mathrm{C}$. This temperature was then used as the refluxing temperature for both methods and the result was as shown in Table 1. It was discovered that the catalyzed Method A afforded product 10a in $68.1 \%$ yield while toluene solvent dependent Method B afforded 10a in $97.3 \%$ yield (Table 1). Since the Method B produced the 10a in higher yield, it was therefore adopted as the synthetic route for the preparation of all other benzimidazoles $10 b-i$. Hence, from the reaction optimization study, the synthesis of 2-substituted benzimidazoles 10a-i was successfully achieved in high yields (83.3 $97.3 \%$ ) by heating the mixture under reflux at a carefully controlled temperature of $85-95{ }^{\circ} \mathrm{C}$ for $9 \mathrm{~h}$ in the presence of toluene solvent . In addition, having obtained these targeted benzimidazole derivatives $10 a-i$, the physico-chemical analyses were carried out and the result is as shown in Table 2. The molecular weight of the compounds varied between 147.18 for $10 \mathrm{a}$ and 238.28 for $10 \mathrm{e}$. The melting points of all the compounds were above $200^{\circ} \mathrm{C}$ which might be as a result of the formation of imino functionality of benzimidazole and possibility of intramolecular hydrogen bonding phenomenon. Four of the compounds (10a, 10c, 10d and 10i) were brown in colour while the rest $(\mathbf{1 0 b}, \mathbf{1 0 e}, \mathbf{1 0 f}$, $10 \mathrm{~g}$ and $10 \mathrm{~h}$ ) were cream coloured crystalline solids. The spectroscopic characterization of the synthesized compounds was carried out using UV-Visible, FT-IR, ${ }^{1} \mathrm{H}-\mathrm{NMR}$ and ${ }^{13} \mathrm{C}-\mathrm{NMR}$ as well as mass spectral data. The results of the electronic transition using uv spectroscopy was investigated in ethanol solution and the result is as presented in the experimental section showing the wavelength $\left(\lambda_{\text {max }}\right)$ and the $\log$ of molar absorptivity $\left(\log \varepsilon_{\max }\right)$. The UV-visible spectrum of $\mathbf{1 0 a}$, as representative sample, gave rise to wavelength $\left(\lambda_{\max }\right)$ at $236 \mathrm{~nm}$, $290 \mathrm{~nm}$ and $407 \mathrm{~nm}$ with $\log \varepsilon_{\max }$ values of 1.78 , 1.32 and 0.85 , respectively. The wavelength at
$236 \mathrm{~nm}$ was as a result of occurrence of $\pi \rightarrow \pi^{*}$ transition of $\mathrm{C}=\mathrm{C}$ confirming the presence of benzenoid ring which was in agreement with earlier established value by Ajani et al. (2013) 2 . The wavelength at $290 \mathrm{~nm}$ was as a result of $\pi \rightarrow n$ transition which may be ascribed to the auxochromic $\mathrm{C}=\mathrm{N}$ group; characteristic of $\mathrm{K}$ bands of $\mathrm{C}=\mathrm{N}$ functional group ${ }^{28}$. A bathochromic shift observed at wavelength of $407 \mathrm{~nm}$ was due to the presence of extensive conjugation, auxochromic character of lone pair on nitrogen in position-1 and chromophoric nature of the benzimidazole ring itself. The infrared analysis was carried out using Bruker FourierTransform Infrared (FT-IR) and the various absorption bands from stretching and bending vibrational frequencies were duly reported. For instance, the IR spectrum of 10 a exhibited the absorption bands at $3384 \mathrm{~cm}^{-1}$ and $3363 \mathrm{~cm}^{-1}$ due to the presence of $\mathrm{N}-\mathrm{H}$ stretching vibration of primary amine $\left(\mathrm{NH}_{2}\right)$ while the band at $3245 \mathrm{~cm}^{-1}$ depicted the presence of $\mathrm{N}-\mathrm{H}$ of secondary amine in the heterocyclic ring portion of 10 a (i.e. $\mathrm{NH}$ of imidazole ring). The stretching frequency of $\mathrm{C}-\mathrm{H}$ aromatic was found at $3021 \mathrm{~cm}^{-1}$ which was further confirmed with the Ar- $\mathrm{H}$ bending frequency at $741 \mathrm{~cm}^{-1}$. The $\mathrm{C}-\mathrm{H}$ stretching vibrational frequency of aliphatic $\left(\mathrm{CH}_{2}\right)$ was observed at 2930 $\mathrm{cm}^{-1}$ while the bands at $1605 \mathrm{~cm}^{-1}$ and $1580 \mathrm{~cm}^{-1}$ depicted the presence of $\mathrm{C}=\mathrm{C}$ aromatic and $\mathrm{C}=\mathrm{N}$ imino functionalities respectively.

Furthermore, the ${ }^{1} \mathrm{H}-\mathrm{NMR}$ and ${ }^{13} \mathrm{C}-\mathrm{NMR}$ of the compounds were run in either DMSO- $\mathrm{d}_{6}$ or $\mathrm{CDCl}_{3}$ depending on the solubility of the particular compound. A proton singlet at d $7.95 \mathrm{ppm}$ was due to presence of $\mathrm{NH}$ of imidazole portion while four aromatic protons were noticed as two proton doublets at $d$ 7.82-7.80 ppm with coupling constant of $8.03 \mathrm{~Hz}$ and the remaining two aromatic protons as a multipet at d 7.17-7.13 ppm. The $\mathrm{NH}_{2}$ linked to methylene group $\left(\mathrm{CH}_{2}\right)$ of $10 \mathrm{a}$ appeared as a two protons triplet at $\mathrm{d} 6.44-6.42 \mathrm{ppm}$ while its two neighbouring protons of appeared as a triplet at $d$ 3.55-3.53 ppm. The neighbouring effect of the $\mathrm{NH}_{2}$ and $\mathrm{CH}_{2}$ on each other was confirmed by the fact that they both have the same coupling constant of $5.78 \mathrm{~Hz}$. The result of the ${ }^{13} \mathrm{C}-\mathrm{NMR}$ of $10 \mathrm{a}$ was run at $100 \mathrm{MHz}$ using deuterated DMSO- $\mathrm{d}_{6}$ as the solvent. It showed the presence of eight carbon atoms with the $d_{c}$ ranging from $142.6 \mathrm{ppm}$ to $41.7 \mathrm{ppm}$. These eight carbon atoms of $10 a$ was made up of seven 
aromatic carbon atoms (142.6-119.2 ppm) and one aliphatic carbon atom of $\mathrm{CH}_{2}$ at $41.7 \mathrm{ppm}$. The mass spectrum of 10a showed the molecular ion peak at $\mathrm{m} / \mathrm{z} 147.03$ with relative intensity of $20 \%$. It is interesting to note that this peak correlated well with molecular weight of $10 \mathrm{a}$. The base peak which was observed at $\mathrm{m} / \mathrm{z} 132.04$ and with relative intensity of $100 \%$ was as a result of loss of $\mathrm{NH}$ (i.e. $\mathrm{M}-\mathrm{NH}$ ). Other daughter fragments observed at $\mathrm{m} / \mathrm{z} 295.04$, $148.01,118.07$ and 76.11 with relative intensities of $10.5 \%, 24.5 \%, 35.3 \%$ and $68.3 \%$ respectively were as a result of some fragmentation processes. The result of elemental analysis did not only correlate well with the molecular masses of all compounds but also showed a consistent minimum difference of not more than \pm 0.25 between $\%$ calculated and $\%$ found for the carbon, hydrogen and nitrogen atoms of compound 10a as well as other compounds (Table 2).

\section{Antibacterial activities}

The antibacterial activity of nine synthesized compounds, 10a-i, was determined in vitro by agar well diffusion technique as described by Russell and Fur $(1977)^{29}$. The media were inoculated with test organisms and a solution of the tested compound in DMSO solvent. The zones of inhibition were measured after $24 \mathrm{~h}$ of incubation. The in vitro general sensitivity testing of the prepared compounds was carried out against three gram positive bacteria (Staphylococcus aureus, Proteus vulgaris and Streptococcus faecalis) and three gram negative bacteria (Klebsiella pneumonia, Pseudomonas aeruginosa and Escherichia coli). Result of antibacterial screening (sensitivity testing) on bacteria with zones of inhibition duly recorded in millimetre $(\mathrm{mm})$ is shown in Table 3 . The choice of use of gentamicin as clinical standards is based on the fact that at low concentrations, gentamicin only inhibits growth of the bacteria through induction of prokaryotic ribosomes to misread $\mathrm{mRNA}^{30}$. Gentamicin also prevents initiation of protein synthesis and leads to death of microbial cells. Also in humans, they have structurally different ribosomes from bacteria, thereby allowing the selectivity of this antibiotic for bacteria. Gentamicin inhibits

Table 2: Results of the physico-chemical parameters of the synthesized compounds

\begin{tabular}{|c|c|c|c|c|c|c|c|c|}
\hline \multirow[t]{2}{*}{$\begin{array}{l}\text { Comp } \\
\text { No }\end{array}$} & \multirow[t]{2}{*}{$\begin{array}{l}\text { Molecular } \\
\text { Formula }\end{array}$} & \multirow[t]{2}{*}{$\begin{array}{l}\text { Molecular } \\
\text { Weight }\end{array}$} & \multirow[t]{2}{*}{$\begin{array}{l}\text { Melting } \\
\text { Pt. (oC) }\end{array}$} & \multirow[t]{2}{*}{$\begin{array}{l}\text { Yield } \\
(\%)\end{array}$} & \multirow[t]{2}{*}{$\begin{array}{l}\text { Sample } \\
\text { Colour }\end{array}$} & \multicolumn{3}{|c|}{$\begin{array}{l}\text { Elemental Analysis Data } \\
\% \text { Calcd. (\%Found) }\end{array}$} \\
\hline & & & & & & C & $\mathrm{H}$ & $\mathbf{N}$ \\
\hline $10 a$ & C8H9N3 & 147.18 & $>200$ & 97.3 & brown & $\begin{array}{c}65.29 \\
(65.31)\end{array}$ & $\begin{array}{c}6.16 \\
(6.18)\end{array}$ & $\begin{array}{c}28.55 \\
(28.52)\end{array}$ \\
\hline $10 b$ & $\mathrm{C} 12 \mathrm{H} 16 \mathrm{~N} 2$ & 188.27 & $>200$ & 85.1 & cream & $\begin{array}{l}76.55 \\
(76.52)\end{array}$ & $\begin{array}{c}8.57 \\
(8.59)\end{array}$ & $\begin{array}{c}14.88 \\
(14.91)\end{array}$ \\
\hline $10 c$ & $\mathrm{C} 12 \mathrm{H} 15 \mathrm{~N} 3 \mathrm{O}$ & 217.27 & $>200$ & 84.3 & brown & $\begin{array}{c}66.34 \\
(66.38)\end{array}$ & $\begin{array}{l}6.96 \\
(7.21)\end{array}$ & $\begin{array}{c}19.34 \\
(19.16)\end{array}$ \\
\hline $10 d$ & C11H13N3 & 187.24 & $>200$ & 89.0 & brown & $\begin{array}{l}70.56 \\
(70.71)\end{array}$ & $\begin{array}{l}7.00 \\
(6.84)\end{array}$ & $\begin{array}{c}22.44 \\
(22.61)\end{array}$ \\
\hline $10 e$ & $\mathrm{C} 12 \mathrm{H} 15 \mathrm{~N} 3 \mathrm{O}$ & 238.28 & $>200$ & 83.3 & cream & $\begin{array}{c}75.61 \\
(75.79)\end{array}$ & $\begin{array}{l}5.92 \\
(6.11)\end{array}$ & $\begin{array}{c}11.76 \\
(11.81)\end{array}$ \\
\hline $10 f$ & C15H15N3 & 237.30 & $>200$ & 84.0 & cream & $\begin{array}{l}75.92 \\
(75.88)\end{array}$ & $\begin{array}{c}6.37 \\
(6.21)\end{array}$ & $\begin{array}{c}17.71 \\
(17.69)\end{array}$ \\
\hline $10 \mathrm{~g}$ & $\mathrm{C} 11 \mathrm{H} 14 \mathrm{~N} 2 \mathrm{~S}$ & 206.31 & $>200$ & 97.1 & cream & $\begin{array}{c}64.04 \\
(63.97)\end{array}$ & $\begin{array}{c}6.84 \\
(6.95)\end{array}$ & $\begin{array}{c}13.58 \\
(13.76)\end{array}$ \\
\hline $10 \mathrm{~h}$ & $\mathrm{C} 12 \mathrm{H} 17 \mathrm{~N} 3$ & 203.28 & $>200$ & 88.2 & cream & $\begin{array}{c}70.90 \\
(70.79)\end{array}$ & $\begin{array}{c}8.43 \\
(8.40)\end{array}$ & $\begin{array}{c}20.67 \\
(20.55)\end{array}$ \\
\hline $10 i$ & $\mathrm{C} 13 \mathrm{H} 11 \mathrm{~N} 3$ & 209.25 & $>200$ & 83.4 & brown & $\begin{array}{c}74.62 \\
(74.81)\end{array}$ & $\begin{array}{l}5.30 \\
(5.43)\end{array}$ & $\begin{array}{c}20.08 \\
(19.98)\end{array}$ \\
\hline
\end{tabular}


bacterial growth by inhibiting protein biosynthesis. Its mechanism of action is similar to that of streptomycin and other aminoglycoside antibiotics.

From the result of sensitivity testing, probable activities of these benzimidazoles family on the tested organisms were categorized based on the size of zone of inhibition (Table 3). Interestingly, it was observed that majority of the compounds exhibited probable and highly promising significant activities based on the large zone of inhibition reported. In fact, many of these benzimidazole derivatives had larger zones of inhibition against all the six organisms when compared with gentamicin standard. Generally speaking, compounds $10 \mathrm{f}$ showed the largest zone of inhibition of $42 \pm 0.10$ $\mathrm{mm}$ against Klebsiella pneumonia while $10 \mathrm{~g}$ had the least zone of inhibition of $19 \pm 0.10 \mathrm{~mm}$ against Proteus vulgaris among all the screened compounds. Compounds $10 \mathrm{c}$ and $10 \mathrm{~h}$ had similar activity of all the tested organisms since they displayed similarity in the size of zones of inhibition ranging from $28 \pm$

Table 3: Result of in vitro antibacterial screening on bacteria with zones of inhibition ( $\mathrm{mm})$

\begin{tabular}{|c|c|c|c|c|c|c|}
\hline$\frac{\text { Organism } \rightarrow}{\text { Comp No } \downarrow}$ & $\begin{array}{c}\text { Staphylococcus } \\
\text { aureus }\end{array}$ & $\begin{array}{l}\text { Proteus } \\
\text { vulgaris }\end{array}$ & $\begin{array}{c}\text { Streptococcus } \\
\text { faecalis }\end{array}$ & $\begin{array}{c}\text { Klebsiella } \\
\text { pneumonia }\end{array}$ & $\begin{array}{l}\text { Pseudomonas } \\
\text { aeruginosa }\end{array}$ & $\begin{array}{c}\text { Escherichia } \\
\text { coli }\end{array}$ \\
\hline $10 a$ & $38 \pm 0.20$ & $35 \pm 0.10$ & $38 \pm 0.20$ & $40 \pm 0.13$ & $30 \pm 0.10$ & $40 \pm 0.20$ \\
\hline $10 b$ & $35 \pm 0.10$ & $30 \pm 0.20$ & $32 \pm 0.20$ & $35 \pm 0.10$ & $20 \pm 0.10$ & $40 \pm 0.10$ \\
\hline $10 c$ & $30 \pm 0.10$ & $28 \pm 0.20$ & $30 \pm 0.10$ & $35 \pm 0.10$ & $32 \pm 0.13$ & $35 \pm 0.10$ \\
\hline $10 d$ & $38 \pm 0.10$ & $20 \pm 0.10$ & $35 \pm 0.10$ & $40 \pm 0.20$ & $35 \pm 0.20$ & $35 \pm 0.13$ \\
\hline $10 e$ & $34 \pm 0.20$ & $20 \pm 0.11$ & $30 \pm 0.10$ & $36 \pm 0.10$ & $36 \pm 0.20$ & $32 \pm 0.20$ \\
\hline $10 f$ & $32 \pm 0.20$ & $30 \pm 0.10$ & $30 \pm 0.10$ & $42 \pm 0.10$ & $32 \pm 0.14$ & $34 \pm 0.10$ \\
\hline $10 \mathrm{~g}$ & $24 \pm 0.10$ & $19 \pm 0.10$ & $32 \pm 0.20$ & $36 \pm 0.12$ & $30 \pm 0.10$ & $34 \pm 0.10$ \\
\hline $10 \mathrm{~h}$ & $28 \pm 0.20$ & $30 \pm 0.14$ & $35 \pm 0.14$ & $32 \pm 0.20$ & $30 \pm 0.13$ & $30 \pm 0.11$ \\
\hline $10 i$ & $36 \pm 0.10$ & $30 \pm 0.20$ & $36 \pm 0.10$ & $36 \pm 0.14$ & $30 \pm 0.29$ & $36 \pm 0.10$ \\
\hline Gent & $10 \pm 0.10$ & $18 \pm 0.10$ & $15 \pm 0.20$ & $07 \pm 0.20$ & $12 \pm 0.14$ & $04 \pm 0.20$ \\
\hline
\end{tabular}

amicin Staphylococcus aureus $\left(\mathrm{G}_{+}\right)$, Proteus vulgaris $(\mathrm{G}+)$, Streptococcus faecalis $(\mathrm{G}+)$, Klebsiella pneumonia (G-), Pseudomonas aeruginosa (G-), Escherichia coli (G-). G+ = Gram positive, G- = Gram negative. Mean \pm Standard deviation of triplicate measurement.

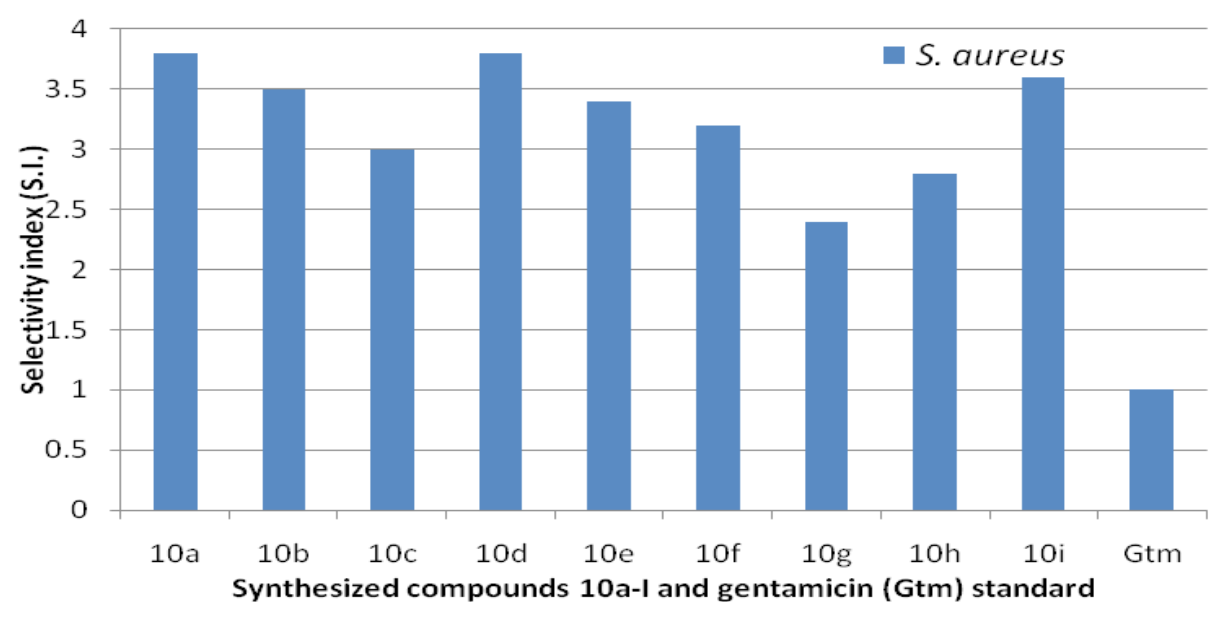

Fig. 2: The result of selectivity index of synthesized compounds using S. aureus (G+ organism) 


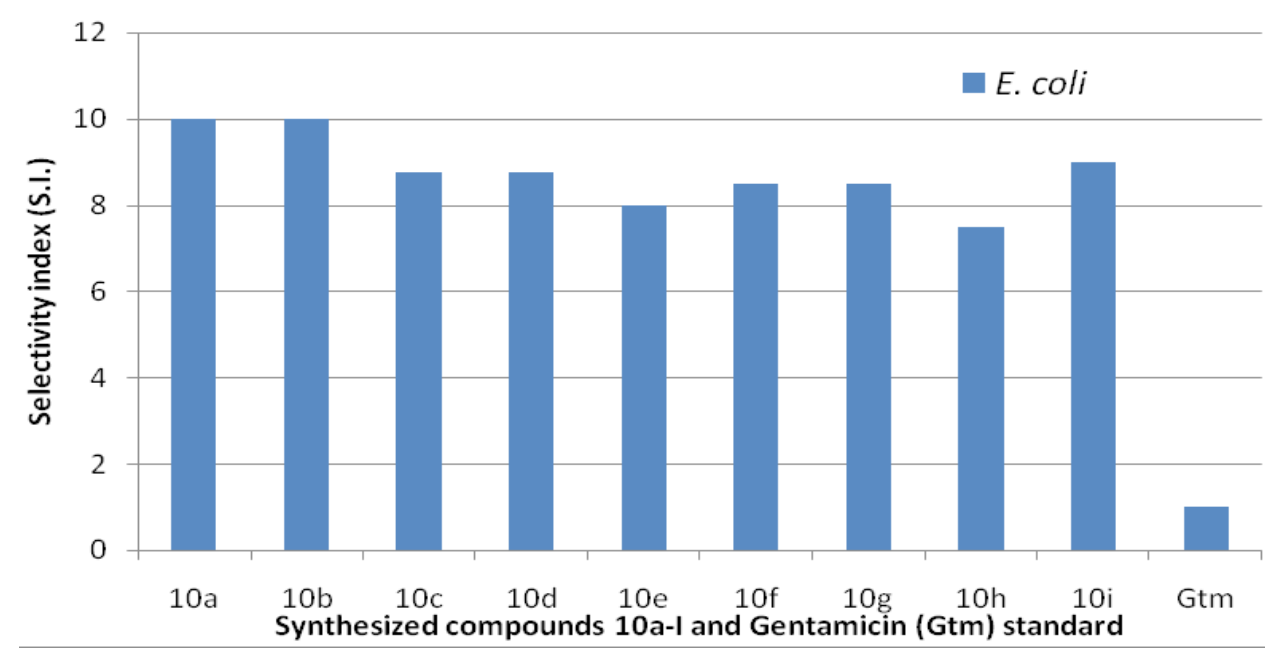

Fig. 3: The result of selectivity index of synthesized compounds using E. coli (G- organism)

$0.20 \mathrm{~mm}$ to $35 \pm 0.10 \mathrm{~mm}$. This similarity in activity of these two compounds could be traceable to the fact that both 10c and $10 \mathrm{~h}$ had two $\mathrm{NH}_{2}$ functional groups. Larger zones of inhibition were experienced upon the screening of all compounds against $S$. aureus, except 10h with Z.O.I. of $24 \pm 0.10 \mathrm{~mm}$ which was an indication that the presence of long aliphatic chain length and thiomethyl group projected an antagonistic effect on the potency of $10 \mathrm{~h}$. The result of screening unveiled 10a (Z.O.I. $=35 \pm 0.10$ $\mathrm{mm}$ ) to be most active while $10 \mathrm{~g}$ (Z.O.I. $=19 \pm 0.10$ $\mathrm{mm}$ ) was the least active against Proteus vulgaris and also being almost similar to that of gentamicin antibiotic (Z.O.I. $=18 \pm 0.10 \mathrm{~mm})$. The screening on third gram positive organism, Streptococcus faecalis, showed 10a (Z.O.I $=38 \pm 0.20 \mathrm{~mm})$ to be most active while 10c, 10e, $10 \mathrm{f}(Z . O . I .=30 \pm 0.10 \mathrm{~mm})$ which were the least active were even two fold more active than gentamicin antibiotic (Z.O.I. $=15 \pm 0.20 \mathrm{~mm}$ ) in the inhibition of the growth of Streptococcus faecalis. Considering the response of three gram negative organisms to compounds $\mathbf{1 0 a - i}$, it was discovered that the efficacy was so high with the Z.O.I. $\geq 30 \pm$ $0.10 \mathrm{~mm}$ except for $10 \mathrm{~b}$ (Z.O.I. $=20 \pm 0.10 \mathrm{~mm}$ ) against the growth of Pseudomonas aeruginosa. Thus, from morphological feature, the synthesized benzimidazoles 10a-i had better potency on the gram negative than the gram positive bacterial isolates. The morphological evidence suggests that the initial binding of the antibiotic disrupts the packing order of lipopolysaccharide of the outer membrane, which ultimately forms holes in the cell envelope and could have led to cell lysis. This was in agreement with the finding of Kadurugamuwa et al. (1993) who revealed that gentamicin has two potentially lethal effects on gram-negative cells ${ }^{31}$, which might have originated from inhibition of protein synthesis and surface perturbation; the two effects in concerted nature make aminoglycoside drugs particularly effective antibiotics.

Furthermore, the comparative study of selectivity index therein was evaluated by using one gram positive (Staphylococcus aureus) and one gram negative (Escherichia coli) organisms. From this result, it was obvious that activity of the targeted compounds on E. coli is stronger than that of the Staphylococcus aureus throughout the screened range. It was also interesting to note that the benzimidazoles 10a-i were more active than the clinical standard gentamicin since all of them have higher selectivity indices than gentamicin. The result of the selectivity index of the synthesized compounds with respect to gentamicin on S. aureus and E. coli are as shown in Fig 2 and Fig. 3 respectively. Against the gram negative representative $E$. coli, compounds $10 \mathrm{a}$ and $10 \mathrm{~b}$ were ten times more active than the gentamicin standard against the growth of the gram negative E. coli. This showed that short length side chain alkyl group led to an improved activity since 10a with methylene side chain exhibited highest activity against $E$. coli growth. Also, compound $10 \mathrm{e}$ $(\mathrm{R}=\mathrm{OH})$ with S.I $=8.00$, was less active than $10 \mathrm{f}$ $(R=H)$ with S.I. value of 8.50 . Although, $10 e$ and 
$10 f$ were structurally related but for the nature of substituent on para position of their phenyl ring. Hence, it could be deduced that the presence of electron donating group $(\mathrm{OH})$ on para position of phenyl ring led to reduction in the activity against E. coli., it is herein suggested that the presence of amino functionality in all the synthesized compounds contributed synergistic effect in their improved antimicrobial efficiencies, just like in aminoglycoside antibiotics. Based on the report from the in vitro screening and selectivity index result, the potency of the compounds 10a H" $10 \mathrm{~d}>10 \mathrm{i}>10 \mathrm{~b}>10 \mathrm{e}>10 \mathrm{f}$ $>10 \mathrm{c}>10 \mathrm{~h}>10 \mathrm{~g}>$ gentamicin regarding inhibition of the growth of $S$. aureus (the representative of the gram positive organisms). In a like manner, the potency of the compounds 10a H"10b > 10 $>10 \mathrm{c}$ $H$ " $10 \mathrm{~d}>10 \mathrm{H}$ " $10 \mathrm{~g}>10 \mathrm{e}>10 \mathrm{~h}>$ gentamicin regarding inhibition of the growth of $E$. coli (the representative of the gram negative organisms). The amalgamation of two or more heterocyclic cores has drawn substantial attention in medicinal chemistry. Hence, combination of amino acid with o-phenylenediamine in the formation of 2-substituted benzimidazole heterocyclic cores have, in no doubt, led to increase in the structural complexity of designed molecules which made them to exhibit and display better biological properties on all the organisms as compared with gentamicin clinical standard.

\section{CONCLUSION}

The synthesis of new 2-substituted benzimidazole derivatives 10a-i was herein successfully achieved in improved yields via solvent dependent approach in toluene. Most of the tested compounds were found to be significantly effective against all the three gram positive bacteria (Staphylococcus aureus, Proteus vulgaris and Streptococcus faecalis) and the three gramnegative bacterial strains (Klebsiella pneumoniae, Pseudomonas aeruginosa and Escherichia coli), among which compounds 10a, 10b, 10f and 10i surfaced out as the most effective antibacterial agents which are some folds more active than the standard gentamicin. Thus, this work will be very useful for further studies in terms of MIC test, toxicity effect and Structural Activity Relationship (SAR) to improve their biological and pharmacological properties for future drug development.

\section{REFERENCES}

1. Ajani, O. O., Isaac, J. T., Owoeye, T. F., Akinsiku, A. A. Int. J. Biol. Chem., 2015, 9, 148-177.

2. Ajani, O. O., Ezeoke, E. K., Edobor-Osoh, A., Ajani, O. A. Int. Res. J. Pure Applied Chem., 2013, 3, 10-21.

3. Walia, R., Hedaitullah, Md., Naaz, S. F., Iqbal, K., Lamba, H. S. Int. J. Res. Pharm. Chem., 2011, 1(3), 565-574.

4. Shiraishi, Y., Sugano, Y., Tanaka, S., Hirai, T. Angew. Chem. Int. Ed., 2010, 49(9), 16561660.

5. Sluiter, J., Christoffers, J. Synlett, 2009, No. 1, 63-66.

6. Trivedi, R., De, S. K., Gibbs, R. A. J. Mol. Catal. A, 2006, 245, 8-11.

7. Chen, Y.-X., Qian, L.-F., Zhang, W., Han, B. Angew. Chem. Int. Ed., 2008, 47(48), 93309333.

8. Molander, G. A., Ajayi, K. Org. Lett., 2012, 14, 4242-4245.
9. Curini, M., Epifano, F., Montanari, F., Rosati, O., Taccone, S. Synlett, 2004, No. 10, 18321834.

10. Sun, X., Lv, X. H., Ye, L. M., Hu, Y., Chen, Y. Y., Zhang, X. J., Yan, M. Org. Biomol. Chem., 2015, 13, 7381-7383.

11. Sontakke, V. A., Kate, A. N., Ghosh, S., More, P., Gonnade, R., Kumbhar, N. M., Kumbhar, A. A., Chopade, B. A., Shinde, V. S. New J. Chem., 2015, 39, 4882-4890.

12. Kalinowska-Lis, U., Felczak, A., Chêciñska, L., Lisowska, K., Ochocki, J. J. Organomet. Chem., 2014, 749, 394-399.

13. Paul, K., Sharma, A., Luxami, V. Bioorg. Med. Chem. Lett., 2014, 24, 624-629.

14. Kamil, A., Akhter, S., Ahmed, M., Rizwani, G. H., Hassan, S., Naeem, S., Jahan, S., Khursheed, R., Zahid, H. Pak. J. Pharm. Sci., 2015, 28(6), 2179-2184.

15. Yadav, G., Ganguly, S., Murugesan, S., Dev, A. Anti-Infect. Agents, 2015, 13(1), 65-77. 
16. Gaba, M., Mohan, C. Med. Chem., 2015, 5(2), 58-63.

17. Ramprasad, J., Nayak, N., Dalimba, U., Yogeeswari, P., Sriram, D., Peethambar, S. K., Achur, R., Kumar, H. S. Eur. J. Med. Chem., 2015, 95, 49-63.

18. Kumar, P. S., Sahoo, J. Orient. J. Chem., 2014, 30(1), 211-217.

19. Rajak, H. Int. J. Chem. Eng. Appl., 2015, 6(2), 142-145.

20. Mavrova, A. T., Yancheva, D., Anastassova, N., Anichina, K., Zvezdanovic, J., Djordjevic, A., Markovic, D., Smelcerovic, A. Bioorg. Med. Chem., 2015, 23(19), 6317-6326.

21. Patil, A., Ganguly, S., Hundiwale, J., Tayade, S. Int. J. Pharm. Chem., 2012, 2(3), 89-92.

22. Luo, Y., Yao, J. P., Yang, L., Feng, C. L., Tang, W., Wang, G. F., Zuo, J. P., Lu, W. Arch. Pharm., 2011, 344(2), 78-83.

23. Zhang, Y., Xu, J., Li, Y., Yao, H., Wu, X. Chem. Biol. Drug Des., 2015, 85, 541-548.

24. Aboul-Enein, H. Y., El Rashedy, A. A. Med. Chem., 2015, 5, 318-325.
25. Kopel, P., Wawrzak, D., Langer, V., Cihalova, K., Chudobova, D., Vesely, R., Adam, V., Kizek, R. Molecules, 2015, 20, 1036010376.

26. Chu, B., Liu, F., Li, L., Ding, C., Chen, K., Sun, Q., Shen, Z., Tan, Y., Tan, C., Jiang, Y. Cell Death Dis., 2015, 6, e1686. doi:10.1038/ cddis.2015.25

27. Barrett, G. C., Elmore, D. T. Sources and roles of amino acids and peptides in: Amino Acids and Peptides, Cambridge University Press, UK, 2004, pp 1-3.

28. Komurcu, S. G., Rollas, S., Uglen, M., Gorrod, J. W. Boll. Chim. Farmac., 1995, 134, 375379.

29. Russel, A. D., Furr, J. R. J. Appl. Bacteriol., 1977, 43, 253-260.

30. Voet D., Voet J. D. Biochemistry 3rd ed.; John Wiley and Sons, Hoboken, 2004, pp 13411342.

31. Kadurugamuwa, J. L., Clarke, A. J., Beveridge, T. J. J. Bacteriol., 1993, 175(18), 57985805. 